\title{
TREES FOR CAVITY-DWELLING BIRDS
}

\author{
JEAN BANCROFT, 306-200 Tuxedo Avenue, Winnipeg, Manitoba. R3P OR3
}

In our present society it seems to be the rule, rather than the exception, to remove standing dead and dying trees. Little do people realize the value of these trees for many species of birds for perching, roosting, and nesting in tree cavities. More importantly, cavitydwelling birds perform a useful function in the balance of Nature by consuming insects.

For several years, during my walks in and around Whytewold on Lake Winnipeg (where our summer cottage is located), I have noticed that there are many standing dead and dying trees in private properties and wooded areas. These trees hold a particular fascination for me and I take great delight in watching to see what they might reveal.

Early every spring I hurry over to view a tall dying aspen poplar which has several cavities of various sizes in its trunk. The largest cavity has been occupied by Grey Squirrels from time to time. Several smaller ones have been the nesting sites of Starling, Hairy Woodpeckers, and Yellow-bellied Sapsuckers. In the spring of 1981 I observed a Downy Woodpecker hollow out a new cavitiy, and I have the good fortune of watching the entire nesting period.

On our property an aged giant oak has, in its gnarled base, a very large cavity made by Nature. From all appearances squirrels have made good use of this cavity during the winters. One summer I received a surprise when I discovered that a pair of white-breasted nuthatches had chosen to nest in it. Imagine my delight when, looking into this cavity through a shaft of light, I saw five nearly fledged young sitting upright in a row, all huddled together.

A standing dead ash had a family of
Tree Swallows nesting in a small cavity for several seasons (until someone chopped the tree down.) A tall old poplar was used by a family of Tree Swallows for several seasons, until the property owners decided to cut down every poplar in their yard. I was present when Tree Swallows came back in the spring of 1981 to this same spot - (I assume it was the whole family from the previous summer, as there were six of them) ${ }^{1}$ only to find that the nesting site had disappeared.

One spring a pair of Black-capped Chickadees decided to excavate a hole in the top of a broke-off dead tree situated in a Caragana hedge. It was with a good deal of interest that I watched the sawdust come flying out of the cavity as they worked.

One of my most interesting finds was a pair of American Kestrels in a brokenoff standing dead poplar in woods near the creek. The first season, 1980, I was unable to locate the nest site until I spotted two recently fledged young sitting nearby in a broken-off tree. In 1981 I went back to the same spot on 30 May and, sure enough, American Kestrels had established a nest in the same cavity. (It probably was the pair from the previous season.) I observed the nest from time to time for 3 weeks, expecting any day that I would be able to see signs of the young. However, a tragedy occurred; one night a very severe windstorm split and felled the tree right at the nest cavity. The adult birds were flying overhead and making a tremendous noise with their calls of "killy, killy, killy." The nest and its contents had been destroyed by this act of Nature.

Near the railway tracks a small 
woodlot borders a farmer's land; this contains many standing dead trees (mostly poplars.) It is a good spot to see many different species, including several varieties of woodpeckers. It is especially a favourite haunt of the Redheaded Woodpecker. Two consecutive seasons I observed these birds nesting in an old tree cavity.

Unnecessary tree-cutting continues, notwithstanding the valuable contribution made by cavity-dwellers. Scientific experiments made to provide a substitute for standing dead and dying trees appear to date to have been unsuccessful. A recent article in Audubon, by Roxanna Sayre, develops this point:

"By now it is a familiar story. First the treecutters dispatch square miles of what they like to refer to as 'over-mature' trees -and leave cavity-nesting wildlife without homes. Then wildlife scientists step in and try to create housing for squirrels, mice, birds, even bears. Nest boxes, the traditional replacement housing, aren't very attractive or long-lasting, and are vulnerable to predation.

"So a couple of U.S. Forest Service staffers in West Virginia decided to help nature provide the decaying trees in which nest holes develop. They cut live branches from healthy oaks and maples and injected them with fungal infection to induce decay. This worked - but very slowly. And it provided homes, but mainly for flying squirrels and a few white-footed mice."

Researchers then decided to use polystyrene and plant plastic trees in a forest infested with spruce budworm

"The managed area had been denuded of good nesting trees and zoologists were trying to lure woodpeckers back to the area to help subdue the plague of budworms. Holes were dug out in most of the trees but no woodpeckers nested. Apparently males couldn't attract females by tapping on the plastic trees because they would not resonate. The scientists now plan to sheath a portion of their phony trees in real plywood."'2

From the foregoing, and from the in- stances I have observed, it is evident that it is of the utmost importance that natural habitat be retained for cavitydwelling birds. Let us become more aware of this and take a greater interest in its protection and management.

PINEL, H.W. 1980. Reproductive efficiency and site attachment of Tree Swallows and Mountain Bluebirds. Blue Jay 38(3): 181 and 183.

SAYRE, ROXANNA. 1981. Creatures. Audubon 83(4): 24. Reprinted with permission from Audubon, the magazine of the National Audubon Society.

\section{GREAT BLUE HERON CONCENTRATIONS}

\section{ART J. DERKSEN, Fisheries Branch,} 1495 St. James St., Winnipeg, Manitoba. R3H OW9

On 17 May 1982, Joe O'Connor and I sighted two large flocks of Great Blue Herons feeding on dry ground. Both of us are familiar with Sandhill Cranes and are certain of the identification. Approximately 40 to 50 birds were in each flock, feeding in open fields near Powderhorn Creek, southeast of Homebrook off PR 328 and near Lake Manitoba. The fields in which the birds were feeding were used for haying and/or pasture. The flocks were within about a quarter mile of each other. The sighting was made about 1300 hours. The weather at the time was overcast, with light intermittent drizzle.

The flocks were fairly tightly knit, with several feet between individuals. They were intent on feeding and were not disturbed by the sounding of the vehicle horn.

According to William H. "Bill" Koonz, the nearest known Great Blue Heron rookeries are all about 20 miles away. 